\title{
Examination of Daily Task Constraint in Technician Routing and Scheduling Problem
}

\author{
Engin Pekel ${ }^{1 *}$

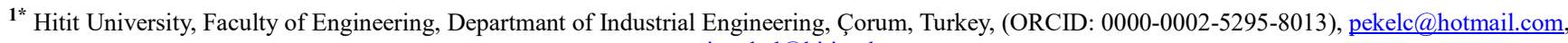 \\ enginpekel@hitit.edu.tr
}

(1st International Conference on Applied Engineering and Natural Sciences ICAENS 2021, November 1-3, 2021)

(DOI: 10.31590/ejosat.995415)

ATIF/REFERENCE: Pekel, E. (2021). Examination of Daily Task Constraint in Technician Routing and Scheduling Problem. European Journal of Science and Technology, (28), 207-212.

\begin{abstract}
This paper deals with a multi-term technician routing and programming problem with a different concept. The problem is that technicians with various skills form teams, and these teams perform the tasks that take in distinct locations. Technicians have daily duty capacities while performing tasks. The cases where overtime costs are allowed by combining different technician numbers are analyzed. Paper provides a single-purpose mixed integer programming method for modeling the problem because the model implemented aims to optimize the travel cost while simultaneously minimizing the amount of overwork. The main issue also specifies the division of technicians with different skills into teams, assignment of tasks with different skill requirements to teams, and routes for each team at the same time. The number of customers visited on a route within the daily customer limit. In addition, the model included exceeding the daily customer limit in the model and bound it to a constraint. The various combinations of the daily normal and over-work number of customers were evaluated and examined their effects on the objective function. Finally, the paper presents computational experiments and analyses to evaluate the efficiency of the proposed mathematical formulation and solution approach. The results show that daily task constraints are effective in employee selection and amount of use.
\end{abstract}

Keywords: Branch and bound, Minimization, Multi period, Technician routing, Technician scheduling.

\section{Teknisyen Rotalama ve Çizelgeleme Probleminde Günlük Görev Kısıtlamasının İncelenmesi}

$\ddot{O} \mathbf{z}$

Bu makale, farklı bir konsepte sahip çok dönemli bir teknisyen rotalama ve programlama problemini ele almaktadır. Sorun, çeşitli becerilere sahip teknisyenlerin ekipler oluşturması ve bu ekiplerin farklı konumlarda yapılan görevleri yerine getirmesidir. Teknisyenlerin görevleri yerine getirirken günlük görev kapasiteleri vardır. Farklı teknisyen numaralarının birleştirilmesiyle fazla mesai maliyetlerine izin verilen durumlar analiz edilmiştir. Çalışma, problemi modellemek için tek amaçlı bir karma tamsayı programlama yöntemi sağlar, çünkü uygulanan model ulaşım maliyetini optimize ederken aynı zamanda fazla çalışma miktarını da en aza indirmeyi amaçlar. Ana konu ayrıca farklı becerilere sahip teknisyenlerin ekiplere bölünmesini, farklı beceri gereksinimlerine sahip görevlerin ekiplere atanmasını ve her ekip için aynı anda rotaları belirtir. Günlük uğranan müşteri sayısı belirlenen limit dahilinde gerçekleşir. Ayrıca model, günlük müşteri limitinin aşılmasını da modele dahil etmiş ve bir kısıtlamaya bağlamıştır. Müşterilerin günlük normal ve fazla çalışma sayılarının çeşitli kombinasyonları değerlendirilmiş ve amaç fonksiyonu üzerindeki etkileri incelenmiştir. Son olarak, makale, önerilen matematiksel formülasyon ve çözüm yaklaşımının etkinliğini değerlendirmek için hesaplamalı deneyler ve analizler sunar. Sonuçlar, günlük görev kısıtlamalarının çalışan seçiminde ve kullanım miktarında etkili olduğunu göstermektedir.

Anahtar Kelimeler: Dal ve sınır, Çok periyotlu, Minimizasyon, Teknisyen çizelgeleme, Teknisyen rotalama

*Corresponding Author: pekelc@hotmail.com, enginpekel@hitit.edu.tr 


\section{Introduction}

Technician routing and scheduling problem (TRSP), this type of problem exists in communication networks and maintenancerepair services. The sustainability of such services in a healthy and planned way is highly dependent on routing and scheduling. In addition, firms or institutions require to manage limited labor resources effectively. The services provided by the firm or institutions involve different types of complex tasks to be performed by technicians with various skills. Also, technicians need to visit distinct geographic areas to meet customer demands. TRSP can be defined as a branch of the vehicle routing problem, [1] including time windows. Therefore, it is NP-Hard [2-3].

The current literature on TRSP approaches from many different aspects. The characteristics of TRSP may include time intervals, skills for a technician, requirements for a task, team building, clustering, learning method, multi-period, single-term, service time, and related activities. Dohn et al. [4] aimed to solve the problem of manpower allocation with a single period and time intervals with an integer programming method. Cordeau et al. [5] suggested single-term team building, routing, and scheduling to perform maintenance-repair tasks in a communications firm. Other single-term studies of the TRSP can also be found $[2,3,6$, 7]. Tang et al. [8] formulated a planned maintenance planning problem for multiple days to maximize the sum of profit from customers. Chen et al. [9] suggested using artificial neural networks for a multi-term technician planning problem and stated that the service time depends on the experience of a technician. In their paper, the authors promote a TRSP under multiple terms, length of service, and travel time and also assign available technicians to teams. Lazakis and Khan [10] proposed an optimization framework for short-term maintenance regarding route planning, scheduling, and cost-minimization. They performed different heuristic and clustering techniques effectively. The reliability of the performed techniques is experimented with by case studies. Çakırgil et al. [11] dealt with the multi-skill workforce scheduling and routing problem in field service operations by considering two objectives: completing higher priority tasks earlier and minimizing total operational costs. They proposed a mixed integer programming model to find Pareto optimal solutions. Mathlouthi et al. [12] dealt with a technician routing and scheduling problem by considering multiple time windows for service, an inventory of spare parts carried by each technician, and tasks. They performed a specified Tabu search coupled with an adaptive memory. Irawan et al. [13] proposed a large neighborhood search metaheuristic to solve the deterministic maintenance routing problem in an offshore wind farm by minimizing the total cost. In addition, they considered the maintenance activities as uncertain conditions and developed a simulation-based optimization algorithm to deal with these uncertainties. Graf [14] proposed a hybrid algorithm that consists of a large neighborhood, local search heuristics, and a decomposition approach to generate competitive solutions at a tight time efficiently. Frifita et al. [15] dealt with a technician routing and scheduling problem by minimizing a linear combination of total weighted distance, over-time, and maximize the served requests. They performed a meta-heuristic algorithm that consists of variable neighborhood search with an adaptive memory and advanced diversity management. Khalfay et al. [16] proposed a greedy randomized heuristic coupled with simulated annealing to deal with the service technician routing and scheduling problem by considering time windows.

Pekel [17] proposed an improved PSO (IPSO) algorithm to solve TRSP using a specific dataset and provided a detailed comparison in the paper.

The rest of this research is organized as follows. Section 2 introduces a definition and mathematical model to the problem. Section 3 explains the branch-and-bound algorithm. In section 4, the case study and consequences are provided in detail. Finally, Section 5 contains the conclusion and future research.

The proposed model structure can be easily applied in any field dealing with technician scheduling. As a result, by providing flexible alternative solutions, both more cost-effective and shorter time to complete the work can be achieved.

The majority of the studies in this field relate to algorithm development that gives better solutions to specified data sets. However, unlike the studies, this paper contributes to the literature by flexing the constraints in the data sets and investigating whether there are better alternatives.

\section{Mathematical Model}

TRSP is a graph that consists of $I$ and $A$ sets and defined as $G(I, A)$. Vertex set $I$ includes a set of $I^{\prime}$ scattered tasks and one dummy node $(o)$ designating the depot, and A represents the arc set. A team $k \in K$ chooses pairs of techniciansm, $n \in M$ and completes tasks. Each team $k$ begins to complete tasks and returns at the depot on each dayd $\in D$. Each $\operatorname{arc}(i, \mathrm{j}) \in$ A relates a visiting $\operatorname{cost} c_{i j}$ that includes the service time $p_{i}$ related to each task $i \in I^{\prime}$. In our model, tasks $i$ and $j$ is not equal to each other. The proficiency level $l \in L$ exists in skill requirement $\in Q$. Next, a solution provides a service plan for completing whole tasks during the planning horizon. Table 1 shows all the notations of the mathematical model. 


\section{Sets}

$\begin{array}{cl}D & \text { Days } \\ I^{\prime} & \text { Tasks } \\ I & \text { Tasks and central depot } \\ A & \text { Arcs } A \subseteq(i, j) \mid i, j \in I \\ \underline{D}_{i} \subseteq D & \text { Allowed travel days of task } i \\ A_{d} \subset A & \text { Arcs } A_{d} \subseteq(i, j) \mid i, j \in \text { Iand } \underline{D}_{i} \cap \underline{D}_{j} \\ K & \text { Technician groups } \\ M & \text { Technicians } \\ L & \text { Proficiency levels } \\ Q & \text { Skills }\end{array}$

Parameters

$\begin{array}{cl}c_{i j} & \text { Traveling cost from task } i \text { to task } j \\ v_{i q} & 1 \text { if task } i \text { requires a proficiency }\{0 \text { or } 1\} \\ g_{m q} & 1 \text { if technician } m \text { has a proficiency }\{0 \text { or } \\ \delta & \text { Allowed number of technicians per tech } \\ r \omega^{\text {cost }} & \text { A unit cost of routine-work number } \\ o w^{\text {cost }} & \text { A unit cost of over-work number } \\ \omega^{\text {max }} & \text { Daily maximum routine-work number } \\ o t^{\text {max }} & \text { Daily maximum over-work number }\end{array}$

Decision variables

$\begin{array}{ll}x_{i j k d} & 1 \text { if technician group } k \text { completes task } i \text { and visits task } j \text { on day } \\ y_{i k d} & 1 \text { if technician group } k \text { performs task } i \text { on day } d, 0 \text { otherwise } \\ z_{m k d} & 1 \text { if technician } m \text { works for team } k \text { on day } d, 0 \text { otherwise } \\ r w_{k d} & \text { Routine-work number } k \text { on day } d \\ o w_{k d} & \text { Over-work numberk on day } d\end{array}$

Each team utilizes exactly $\delta$ technicians, and $\delta=2$ is chosen as the authors do [18-19]. However, the mathematical model enables different values for $\delta$. A team of technicians with different individual skills has to meet the talent needs of each task. If teams are overqualified than the task requires, no cost comes out. Team arrangements are not allowed within the working day. However, diverse team configurations on various days are allowed. A technician works for at most one team per day. Equation (1) aims to minimize the cost of traveling, routine-work, and over-work number.

$$
\begin{gathered}
\min Z=\sum_{(i, j) \in A} \sum_{k \in K} \sum_{d \in D} c_{i j} x_{i j k d}+r \omega^{\cos t} \sum_{k \in K} \sum_{d \in D} r w_{k d} \\
+o w^{\cos t} \sum_{k \in K} \sum_{d \in D} o w_{k d} \text { (1) } \\
\sum_{k \in K} \sum_{d \in D} y_{i k d}=1 \quad \forall i \in I^{\prime} \quad \text { (2) } \\
\sum_{j:(i, j) \in A_{d}} x_{i j k d}=y_{i k d} \forall i \in I^{\prime}, \forall k \in K, \forall d \in D \quad(3) \\
\sum_{j:(o, j) \in A_{d}} \sum_{k \in K} x_{o j k d} \geq 1 \quad \forall d \in D \quad(4) \\
\sum_{i:(i, o) \in A_{d}} \sum_{k \in K} x_{i o k d} \geq 1 \quad \forall d \in D \quad(5) \\
\sum_{i h k d}-\sum_{j:(h, j) \in A_{d}} x_{h j k d}=0 \quad \forall h \in I^{\prime}, \forall k \in K, \forall d
\end{gathered}
$$

$$
\begin{gathered}
\sum_{k \in K} z_{m k d} \leq 1 \quad \forall m \in M, \forall d \in D \quad \text { (7) } \\
\sum_{m \in M} z_{m k d}=\delta \quad \forall k \in K, \forall d \in D \quad \text { (8) } \\
v_{i q l} y_{i k d} \leq \sum_{m \in M} g_{m q l} z_{m k d} \forall i \in I^{\prime}, \forall q \in Q, \forall l \in L, \forall k \in K, \forall d \\
\in D \quad(9) \\
r \omega_{k d} \leq \omega^{\max } \forall k \in K, \forall d \in D \quad(10) \\
o w_{k d} \leq o t^{\max } \forall k \in K, \forall d \in D \quad(11) \\
x_{i j k d}, y_{i k d}, z_{m k d} \in\{0,1\} \quad \forall(i, j) \in A, \forall m \in M, \forall k \in K, \forall d \\
\in D \quad(12)
\end{gathered}
$$

Equations (2) and (3) ensure to meet all duties are shared to technician groups on the assigned days. Each technician group begins and completes its planned duties within the central depot in equations (4) and (5). Each day must have at least one scheduled technician group. Equation (6) assures the sequence of duties in a technician group and on a day in which visiting a task location. Equation (7) ensures that a technician cannot be employed by more than one team per day and Equation (8) provides the technicians in each technician group. Equation (9) ensures that the skills of the chosen technicians must meet the skill requirements of a duty. Equation (10) ensures that the routingwork number must not exceed the pre-defined value for the routing-work. Equation (11) ensures that the routine-work number must not exceed the pre-defined value for the over-work. Equation (12) declares that $x_{i j k d}, y_{i k d}, z_{m k d}$ are binary variables. 


\section{Branch and Bound}

Branch-and-bound is a divide-and-conquer strategy that decomposes the problem into subproblems on a tree structure called a branch-and-bound tree. The decomposition mechanism of the algorithm: If $\mathrm{S}$ is decomposed into $\mathrm{S} 1$ and $\mathrm{S} 2$, thus defining two sub-problems. Here, new sub-problems obtained by decomposition can be decomposed into sub-problems in the following process. This process is called branching. Subproblems S1 and S2 are called branches created at node S. Therefore, each sub-problem obtained in solving the problem represents a node in the tree. Branching is not necessarily bidirectional, and multi-directional branching is possible [20].

For the minimization problem discussed in the paper, an upper bound is updated along with the branch-and-bound algorithm and used to prune the nodes. Nodes are pruned because of infeasibility, insufficient bound, and optimal results. If a node is not pruned, it is understood that the specified situations do not occur. In this case, the decomposition process continues into smaller subproblems.

\section{Results}

This part provides certain combinations of routine-work and overwork limits. Limit ranges of 3 to 6 are preferred. The daily limit amount that will be less than three will make the problem infeasible, so daily lower limit combinations start from 3 . While the amount of overworking greater than six does not increase the amount of overwork, it increases the amount of daily routinework. As a result, daily limit amounts between 3 and 6 were reported. Table 2 shows the combinations of over-work and routine-work numbers.

The above table provides the number of customers visited on a route within the daily customer limit. In addition, the model included exceeding the daily customer limit in the model and bound it to a constraint. The various combinations of the daily normal and over-work number of customers were evaluated and examined their effects on the objective function. It is seen that $o t^{\max }$ and $\omega^{\max }$ values take values between 3-6. When ot $^{\max }$ and $\omega^{\max }$ values are equal and equal to 3 , the solution cost is 641.80 , and $200(31.16 \%)$ of this cost is due to over-work. The solution cost tends to decrease when the $o t^{\max }$ value is fixed at 3 and the $\omega^{\max }$ value is increased. When the $o t^{\max }$ value is 4 and the $\omega^{\max }$ value is increased, a downward trend appears again. Finally, when the $o t^{\max }$ value is 6 , the solution cost reaches its lowest value and the increase or decrease of the wmax values does not affect it in any way. There is no over-work cost since the number of jobs to be completed per day does not exceed 6 or more.

Figure 1 shows the usage of technicians concerning different work combinations. When Figure 1 is examined, it is seen that the most used technician is 1 (37), 3 (27), 5 (27), 6 (20), 4 (18), 7 (14), 8 (12), and 2 (5), respectively. There is a $100 \%$ utilization rate as the most used technician number 1 is used in all combinations.

Considering the daily limit combinations created, the usage rate of the technicians used for each combination varies. In this case, forming the daily usage amount with different constraints creates a difference in the solution. This situation also affects the cost and over-work cost.

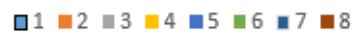

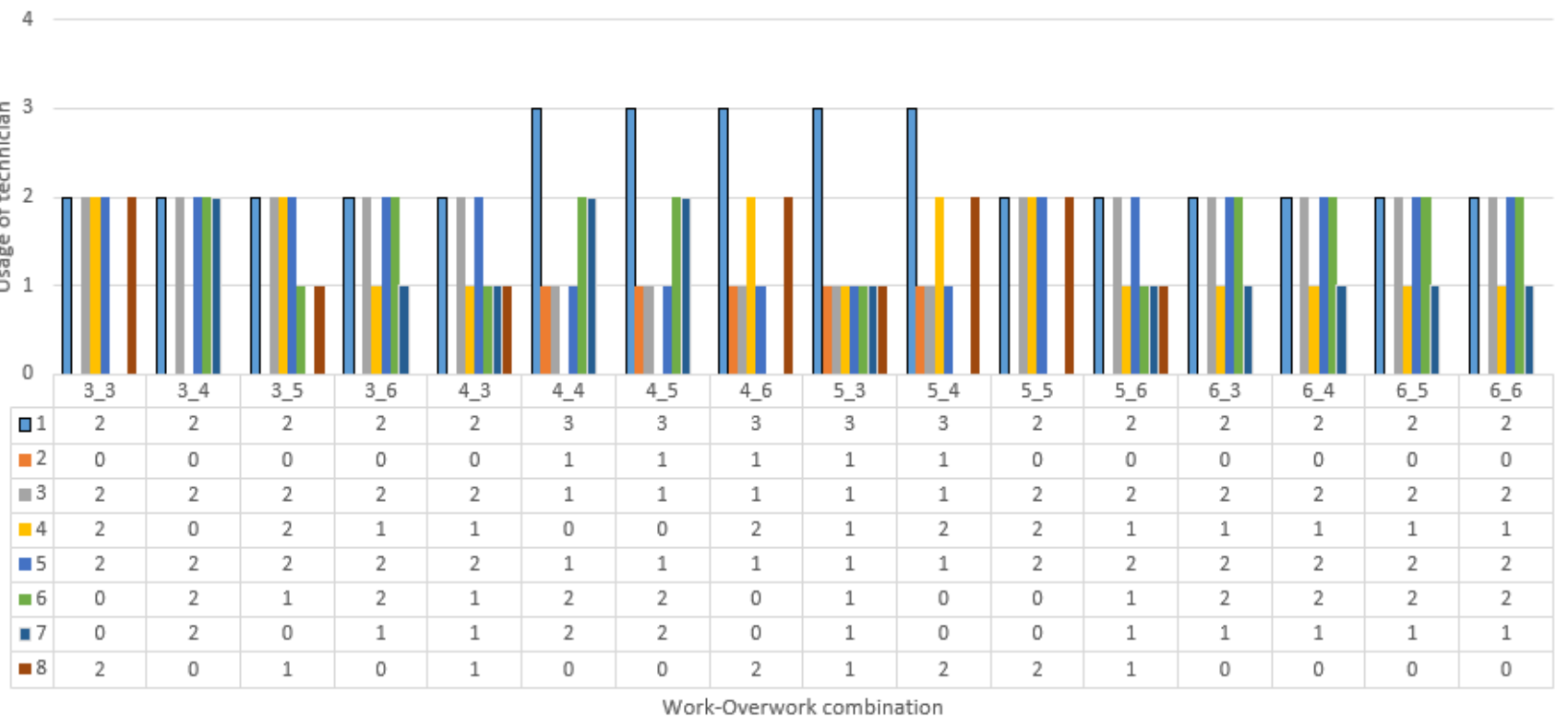

Figure 1. Usage of technicians with regard to different combinations 
Table 2.The attributes of different work limit combinations

\begin{tabular}{cccccc}
\hline${ }^{\max }$ & $\omega^{\max }$ & Solution Cost & Over-Work Cost & Technicians & Task of Route \\
\hline 3 & 3 & 641.80 & 200.00 & $\{(1,4),(1,8),(3,5),(5,8),(3,4)\}$ & $\{5,5,5,5,5\}$ \\
3 & 4 & 638.60 & 200.00 & $\{(1,6),(3,7),(5,6),(1,7),(3,5)\}$ & $\{4,5,4,5,6\}$ \\
3 & 5 & 636.60 & 200.00 & $\{(1,6),(3,5),(1,4),(5,8),(3,4)\}$ & $\{3,3,7,7,5\}$ \\
3 & 6 & 636.60 & 200.00 & $\{(3,4),(1,7),(1,6),(3,5),(5,6)\}$ & $\{3,7,5,3,7\}$ \\
4 & 3 & 588.60 & 140.00 & $\{(5,6),(3,7),(1,4),(1,8),(3,5)\}$ & $\{6,5,5,5,4\}$ \\
4 & 4 & 586.60 & 140.00 & $\{(1,6),(1,7),(1,2),(3,7),(5,6)\}$ & $\{3,7,3,5,7\}$ \\
4 & 5 & 586.60 & 140.00 & $\{(1,6),(1,7),(1,2),(3,7),(5,6)\}$ & $\{3,7,3,5,7\}$ \\
4 & 6 & 586.60 & 140.00 & $\{(3,4),(1,8),(1,4),(5,8),(1,2)\}$ & $\{5,3,7,7,3\}$ \\
5 & 3 & 538.60 & 20.00 & $\{(1,4),(1,8),(1,2),(3,7),(5,6)\}$ & $\{5,5,4,5,6\}$ \\
5 & 4 & 538.60 & 20.00 & $\{(1,2),(5,8),(1,4),(1,8),(3,4)\}$ & $\{4,6,5,5,5\}$ \\
5 & 5 & 538.60 & 20.00 & $\{(1,4),(5,8),(3,5),(1,8),(3,4)\}$ & $\{4,6,5,5,5\}$ \\
5 & 6 & 538.60 & 20.00 & $\{(5,6),(1,8),(3,5),(1,7),(3,4)\}$ & $\{6,5,4,5,5\}$ \\
6 & 3 & 491.80 & 0.00 & $\{(3,4),(1,7),(5,6),(3,5),(1,6)\}$ & $\{5,5,5,5,5\}$ \\
6 & 4 & 491.80 & 0.00 & $\{(3,4),(1,7),(5,6),(3,5),(1,6)\}$ & $\{5,5,5,5,5\}$ \\
6 & 5 & 491.80 & 0.00 & $\{(3,4),(1,7),(5,6),(3,5),(1,6)\}$ & $\{5,5,5,5,5\}$ \\
6 & 6 & 491.80 & 0.00 & $\{(3,4),(1,7),(5,6),(3,5),(1,6)\}$ & $\{5,5,5,5,5\}$ \\
\hline
\end{tabular}

\section{Conclusion}

This paper performed the branch and bound method to solve TRSP without time windows. The TRSP consists of the assignment of technicians into teams, the assignment of teams to tasks, the construction of routes, and the selection of the day on which a service is provided by considering the proficiency level of workers and the proficiency requirement of the task. The following findings were reached by considering the paper;

- Mostly the number 1 technician was used, and it has a usage rate of $100 \%$ since it is preferred in all combinations.

- The usage rate of the technicians used for each combination varies and this makes the solutions different.

- Due to the nature of this problem set, examining combinations of daily transaction limits between 3 and 6 gives the opportunity to evaluate different solutions.

Future studies may be carried out on alternative scenarios by considering time windows and different exact and heuristic methods.

\section{Acknowledge}

"The author has no conflict of interest, financial or otherwise."

\section{References}

[1] B. Moradi, The new optimization algorithm for the vehicle routing problem with time windows using multi-objective discrete learnable evolution model. Soft Computing, 2019. p.1-29.

[2] A.A. Kovacs, S.N Parragh, K.F. Doerner, and R.F. Hartl, Adaptive large neighborhood search for service technician routing and scheduling problems, J Scheduling, 2012. 15, p.579-600.

[3] V. Pillac, C. Gueret, and A.L. Medaglia, A parallel matheuristic for the technician routing and scheduling problem, Optimization Letters, 2013. 7, p.1525-1535.

[4] A. Dohn, E. Kolind, and J. Clausen, The manpower allocation problem with time windows and job-teaming constraints: A branch-and-price approach, Computers and Operations Research, 2009. 36, p.1145-1157.
[5] J.F. Cordeau, G. Laporte, F. Pasin, and S. Ropke, Scheduling technicians and tasks in a telecommunications company, Journal of Scheduling, 2010. 13, p.393-409.

[6] S. Bertels, and T. Fahle, A hybrid setup for a hybrid scenario: combining heuristics for the home health care problem, Computers and Operations Research, 2006. 33, p.2866-2890.

[7] J.Y. Xu, and S.Y Chiu, Effective heuristic procedures for a field technician scheduling problem, Journal of Heuristics, 2001. 7, p.495-509.

[8] H. Tang, E. Miller-Hooks, and R. Tomastik, Scheduling technicians for planned maintenance of geographically distributed equipment, Transportation Research Part E: Logistics and Transportation Review, 2007. 43, p.591-609.

[9] X. Chen, M. Hewitt, and B.W Thomas, An approximate dynamic programming method for the multi-period technician scheduling problem with experience-based service times and stochastic customers, Internation Journal of Production Economics, 2018. 196, p.122-134.

[10] I. Lazakis, and S. Khan, An optimization framework for daily route planning and scheduling of maintenance vessel activities in offshore wind farms. Ocean Engineering, 2021. $225,108752$.

[11] S. Çakırgil, E. Yücel, and G. Kuyzu, An integrated solution approach for multi-objective, multi-skill workforce scheduling and routing problems. Computers \& Operations Research, 2020. 118, 104908.

[12] I. Mathlouthi, M. Gendreau, and J.Y. Potvin, A metaheuristic based on Tabu search for solving a technician routing and scheduling problem. Computers \& Operations Research, 2021. 125, 105079.

[13] C.A. Irawan, M. Eskandarpour, D. Ouelhadj, and D. Jones, Simulation-based optimisation for stochastic maintenance routing in an offshore wind farm. European Journal of Operational Research, 2021. 289(3), p.912-926.

[14] B. Graf, Adaptive large variable neighborhood search for a multiperiod vehicle and technician routing problem. Networks, 2020. 76(2), p.256-272.

[15] S. Frifita, I. Mathlouthi, and A. Dammak, An Efficient VNS Algorithm to Solve the Multi-Attribute Technician Routing and Scheduling Problem. International Journal of Applied Metaheuristic Computing (IJAMC), 2020. 11(1), p.23-35.

[16] A. Khalfay, A. Crispin, and K. Crockett, (2019, September). Solving the service technician routing and scheduling problem with time windows. In Proceedings of SAI 
Intelligent Systems Conference (p. 1168-1177). Springer, Cham.

[17] E. Pekel, Solving technician routing and scheduling problem using improved particle swarm optimization. Soft Computing, 2020. 24(24), 19007-19015.

[18] E. Pekel. and S.S. Kara, Solving fuzzy capacitated location routing problem using hybrid variable neighborhood search and evolutionary local search. Applied Soft Computing, 2019. 83, 105665.

[19] E. Zamorano, and R. Stolletz, Branch-and-price approaches for the multiperiod technician routing and scheduling problem. European Journal of Operational Research, 2017. 257(1), 55-68.

[20] K. Kianfar, Branch-and-Bound Algorithms. Wiley Encyclopedia of Operations Research and Management Science. 2010. 